\title{
Development of Instrument for Measurement of the Organizational Alignment - from Vox Organizationis to "Four Organizational Culture Types and Four Leadership Styles"
}

\author{
Marjan I. Bojadjiev ${ }^{1,2}$ \\ ${ }^{1}$ Department of Management, University American College Skopje, Republic of North Macedonia \\ ${ }^{2}$ Department of Management and Law, University Tor Vergata Rome, Italy
}

Received July 31, 2019; Revised October 22, 2019; Accepted October 27, 2019

Copyright@2019 by authors, all rights reserved. Authors agree that this article remains permanently open access under the terms of the Creative Commons Attribution License 4.0 International License

\begin{abstract}
For a modern organization, it is not enough to only have solid organizational culture, but the organization should be well aligned. Many organizations strive to measure their organizational cultures and their alignment through different models or by adopting internal methods. Despite the great importance of organizational alignment, there is no standardized instrument for measuring it. Therefore, alignment becomes the main focus in theoretical analysis and effort to design an instrument which is verified, easily implementable and measurable in the field of management and organizational culture. This paper has a twofold nature, the first is to give a historical approach to a development of an instrument for measuring organizational culture, leadership styles and their alignment called "Vox Organizationis", and the second is to propose modification and simplification of the same instrument. The birth year of "Vox Organizations", as a starting point for a holistic vision of the organization, is 2011. This instrument enables exploration of the alignment level between organizational culture, leader's values, organizational structure as well as organizational strategy. As of 2019, we propose new version of the instrument under the name Vox 2.0. It has two modifications and one add on. The two modifications are Vox Standard and Vox Standard Plus (Vox Standard +), and add on is Vox Extended, which includes change management consultancy. "Vox Standard" is to measure the alignment between Organizational culture and Leader's values. "Vox Standard Plus" (Standard + Formal) is to measure the alignment between Organizational culture, Leader's Values and the Formal part of the organization. They are both based on the Four Culture Types (4CT) and Four Leadership Types (4LT). "Vox Extended" - as "add on that includes Change Management Intervention, if the organization is severely nonaligned.
\end{abstract}

Keywords Organizational Alignment, Vox
Organizations, Organizational Culture

\section{Introduction}

We published our first "Vox paper" in 2011. Vox Organizationis was designed as an instrument for measuring the level of organizational alignment in the organization. The name is derived from the Latin words: "Vox" meaning "Voice" and "Organizationis" meaning organization. So, we can translate Vox Organizationis as the Voice of the Organizations.

The model was based on the alignment between: organizational culture, or values of the members of the organization, leadership style or values of the leader and the formal part of the organization. As it can be seen, we are using values and culture and values and leadership style as interchangeable terms.

Why these three elements? Organizational culture is crucial for outstanding company performance (Odiakaose, 2018). However, it is important that the organizational culture is aligned with organizational structure, business strategy and leaders values (Quiros, 2009). For sure, it can be said that organizations which are aligned perform more efficiently. This study presents another approach to define, explain and measure organizational culture and alignment.

Alignment is measured through three elements: culture, values and the formal part of the organization. In the research history, there have been a various modifications of the alignment measurement: culture and leader's values, or culture and leader's values and the formal part.

No matter which modification of the instrument was used, the elements were analyzed through four 
dimensions:

1. Decision Making Style, which is related to the decision-making and behavior policies of the company and is measured on two poles: Autocratic versus Participative or Democratic.

2. Work Environment, which is related to the social care or the human relations within the company and is measured on two poles: Cold Versus Warm Work Environment.

3. Organizational Openness, which is related to the collaboration of the members of the organization and cooperation between the organization and its environment and is measured on two poles: Closed Versus Open Organization.

4. Entrepreneurial Orientation, which is related to the tendency toward risk taking by the company and its employees and is measured on two poles: Conservative or Managerial (or Risk averse) and Entrepreneurial or Open to risk.

This model, this reasoning was our modus vivendi in the period 2011-2018. We've published numerous papers based on the above mentioned four dimensions (Bojadjiev, Tomovska Misoska, Mirocevic and Stefanovska-Petkovska, 2018; Bojadjiev,Kostovski, Handjiski Krliu and Shindilovski, 2017; Bojadziev, Naumovski, Tomovska Misoska and Stefanovska Petkovska, 2016; Bojadziev, Tomovska Misoska, Pesev and Stefanovska Petkovska, 2016; Limani, Tomovska-Misoska and Bojadziev, 2015).

The highlight of this activity is the "decision for patent protection" in 2018.

However in terms of practical application we have had problems for larger acceptance of the model.

One of the signs that model should be improved and simplified was that many master theses we have mentored actually opened different pathways. For instance we have examined the alignment between culture and leader's values only (Naumovski et al. 2016), or alignment between all three elements (Pesev et al). This is why we came up with a new simplified concept. The concept of reducing of the four dimensions into two: Decision making Style and Entrepreneurial Orientation.

The main purpose of this paper is to look back on all Vox papers developed so far and to present the new simplified Vox model. The simplification on two dimensions has its justification in theory, for instance Ohio State University and University of Michigan (Hussain and Hasan, 2016) and many others. We have not conducted any research yet. This will be the next step. The next step will be to test our new model and measure its efficiency. However, we are proposing original definitions for: Organizational culture, Leadership and Alignment.

\section{Literature Review}

In this section we shall discuss the theoretical backgrounds of the organizational alignment on the three "elements" relevant for the Vox Model: organizational culture, leader's values \& leadership styles and the formal part of the organization.

Why did we embark on such a journey? Why do we consider the values so important for organizational effectiveness? Why is alignment so important?

We live in a world where it is very popular to use phrases like: "People are our most important asset” (Deen, 2011). Richard Branson is famous for the saying "Clients do not come first. Employees come first” (Mistry, 2017). Employees' values are commonly known as organizational culture. At this moment we would like to point out the following: "Organizational Culture can be considered one of the determinants of organizational efficiency" (Aktas et al., 2011).

If we take into account Ohio University leadership styles (Schriesheim et al., 1979), we believe that both autocratic and democratic approaches to leadership are present, and that both approaches are valid in the XXI century (Fiaz et al., 2017). Furthermore, varieties in leadership styles tend to be present both in emerging countries as well as in the developed world, in the corporations as well as in the small and medium sized companies (Mihai, 2015).

In modern businesses, there are varieties of leadership styles, whereas the most on the two poles would be autocratic and democratic leadership style with many variations in between. There is a body of research in the field of relationships between leadership and culture (Bass et.al, 1993), but there is a limited evidence that discusses the relationship between leadership and organizational culture (Ogbonna and Harris, 2000; Fiedler, 1996; Schein, 1992). Furthermore, we believe that it is important to measure the level of alignment between the "values of members" i.e. organizational culture and "values of the leader" i.e. "leadership style". According to our view, "values of members" represent the culture within the organization, while the values of the leaders represent the style that the leader uses within the organization.

\subsection{Organizational Culture}

The strands of research regarding organizational culture have gone into different directions. One strand of research and thinking examines the relationship between organizational culture and individual behavior and outcomes, such as person-culture fit (O’Reilly et.al., 1991) and the relation between organizational culture and different individual outcomes (Jaivisarn, 2010; Nazir, 2005; Singh, 2007). Another strand leads to understanding the relationship between the national and organizational culture (Hofstede, 1998). Finally tying the organizational culture to effectiveness (Denison and Mishra, 1989; Dickson, et.al., 2000) is tying organizational culture to the functioning of the organizations as a whole (Bojadjiev et al., 2011). 
In this paper we shall focus on the classifications of organizational culture that we deem relevant for the Vox Model. Bojadjiev et al., (2011) states that: "Theoretical framework based on organizational values, measured through organizational practices and perceptions of the member, is called Competing Values Framework (Cameron and Quinn, 2006). The theoretical framework for this instrument has been empirically designed using the Organizational Culture Assessment Instrument (OCAI), which uses taxonomy such as: clan (the organization bears similarity to a family), adhocracy (adaptability, flexibility and creativity are promoted and the company is future-oriented), hierarchy (the organization put emphasize on internal control focus and it is structured and formalized) and market (the organization puts emphasis on external control focus) (Cameron and Quinn, 2006).

Another model that we would like to build upon is Hofstede's. He constructed six key dimension of organizational culture as a result of empirical testing. Those are: process oriented vs. result oriented; employee oriented vs. job oriented; parochial vs. professional; open system vs. closed system; loose vs. tight control; normative vs. pragmatic culture (Hofstede et.al., 1990).

The last model we shall mention for this occasion is Denison Consulting. It is a consulting and practitioner based model rather than theoretical and research based model. However it seems that it has its advantages and is becoming widely used. Denison model suggests that there are four main dimensions: adaptability; mission consistency; involvement and three sub-dimensions for each dimension respectively. Adaptability refers to creating change, customer focus, and organization learning. Mission refers to the strategic intent, goals, objectives and vision of the organization. Consistency refers to the coordination, integration and core values, while involvement refers to the capability development, team orientation and empowerment. Thus the overall model is actually based on twelve culture types (Denison, 2018).

\subsection{Leader's Values}

We would like to mention the work of the some authors that have examined these relationships: the first theory that defined the organizational culture based on the relationship between the leadership style and organizational performance and culture is that of Ogbonna and Harris (2000). They discern four distinct types of culture: innovative, competitive, bureaucratic, and communitarian, and three types of leadership styles: participative, supportive and instrumental. Then, they measured the performance of the company using the customer satisfaction, the sales growth volume, the market share and the competitive advantage. They found that the competitive and innovative cultures are associated with the organizational performance. They found also that strongly shared values contribute to the organizational performance, but only if the organizational culture is oriented towards the external environment. Regarding the leadership style, Ogbonna and Harris (2000) found significant indirect effect on organizational performance and strong association with competitive, as well as, with innovative cultures. Supportive and participative leadership styles were positively related to organizational performance, while instrumental leadership was negatively related (Bojadjiev et.al, 2017).

\subsection{Organizational Alignment}

Semler (1997) defines organizational alignment as the degree to which organizational design, strategy and culture are cooperating to achieve the same desired result. In addition, organizational alignment requires transformation in an organization. That is, top-to-bottom approach in which the leadership of the organization plays a key role in communicating the goals and expectations of the employees and energizing them with providing a strong company vision to follow (Freifeld, 2013).

Our former colleague and Vox Team member, Ms. Ana Krleska (2015), argued in her master thesis that: "Organizational alignment has become an important aspect of the strategy of organizations since it is seen as a way to influence organizational effectiveness according to Tosti (2007)". She also mentions Nadler and Tushman (1989), who argue that the level of congruence of several aspects of organizations leads to optimization of companies' performance. Then, she emphasizes that "organizations that are aligned minimize losses by optimizing resources." In the same direction Schneider et al. (2003) argue that when organizational elements are mutually reinforcing one another and cooperate in order to achieve the same goals, they lead towards higher quality of operations. Krleska (2015) suggests that "the process of alignment becomes more complicated with globalization, increasing customer demands and technological development."

Finally, there is a body of knowledge which considers the change management, or better put, lower quality change management leads towards a situation where the organization is simply not aligned. (Merron, 1994)." Not only scholars, but practitioners and consultants do also emphasize this link (Hinshaw, 2015).

\section{Vox Research - History}

Vox research had been conducted at University American College Skopje (UACS) in the period 2011-2018. The first paper in this series is the above mentioned Bojadziev et al. from 2011, which discusses the need for the new instrument. Then, we asked our MBA students to focus on a single research topic being 
Organizational Alignment. In this series we produced ten master thesis, out of which five have been published as papers in journals. Topics included measuring organizational alignment through implications of Vox in many industries such as: finance sector, food industry, ICT sector, higher education, electro-engineering industry, public sector and consumer goods sector. ${ }^{\mathrm{i}}$ More than 35 companies took part in the validation of the Vox Organizations instrument and more than 1,300 questionnaires for organizational culture were distributed and lately it has started to be implemented internationally, in the Republic of Turkey and the Republic of Cape Verde.

\subsection{Vox Research: "Culture" and "Leader's Values"}

As part of the broader model, the instrument for measurement of organizational culture is based on four dimensions: decision making and behavior; people versus task orientation; innovativeness and risk taking; and open versus closed system.” (Bojadziev et al., 2011). Table 1 shows that the model comes which 16 types of organizational culture, derived from the two poles of the four dimensions:

Table 1. Vox Organizationis model

\begin{tabular}{|c|c|c|}
\hline Pole & Dimension & Pole \\
\hline Autocratic & $\begin{array}{c}\text { Decision making and } \\
\text { Behavior }\end{array}$ & Participative \\
\hline Cold & Work environment & Warm \\
\hline Closed & Organizational Openness & Open \\
\hline Risk Averse & Entrepreneurial Orientation & Entrepreneurial \\
\hline
\end{tabular}

The dimensions are bipolar and were measured on four point Likert type scale. This type of research has its precedents in the research (Cameron and Quinn, 2006) and (Hofstede et.al. 1990).

The dimension "Decision making and behavior" has been emphasized in the Organizational Culture Inventory (Cooke and Szumal, 2000). The dimension "Innovativeness and risk taking" is similar to the Organizational Culture Profile (OCP) (O’Reilly et al., 1991) and the dimension "people versus task orientation" is included in a number of other instruments (Cooke and Szumal, 2000; Hofstede, et.al., 1990). The actual design of the instrument based on the aforesaid dimensions is more thoroughly discussed in previous research (Bojadjiev et al., 2011). There used to be sixteen possible variations of the dimension types. This is why in this paper we propose more applicable system with only four possible types: Entrepreneurial Autocracy; Entrepreneurial Democracy, Conservative or Managerial Autocracy, and Conservative or Managerial Democracy. We shall name this typology as Four Culture Types (4CT). The appropriate typology of leadership styles will be named Four Leader's Types (4LT).

\subsection{Vox Research "Alignment"}

"Organizational alignment alludes to arranging the different parts of an organization so they can cooperate harmoniously and head in the same direction; in this manner, they can seek common objectives, enhance execution and maintain competitive advantage" (Weiser, 2000)

"We understand Organizational Alignment as common sharing of similar values between organizational members and its leader, and embedment of the same values in the formal part of the organization."

Our definition encompasses shared values and perceptions among organizational members and its leader. However we believe that the alignment to work has to be embedded in the formal policies, like for instance remuneration and promotion policy, formal organizational structures and job descriptions, and procedures that regulate behavior.

We do not believe that a single organization can consider itself as an "entrepreneurial organization" without having policy that encourages risk taking or any other form of support for making losses while experimenting on the products.

\subsection{Vox Research - Results Displayed}

The results can be displayed in two ways. The first is to present them as a qualitative study with the identification of Organizational Culture Type and Leader's type, followed by a discussion that explains our taxonomy of culture and leader's types. The above mentioned can be also presented via charts or radar. ${ }^{\text {ii }}$ Please refer to Figure 1 for how Vox results from the research are displayed.

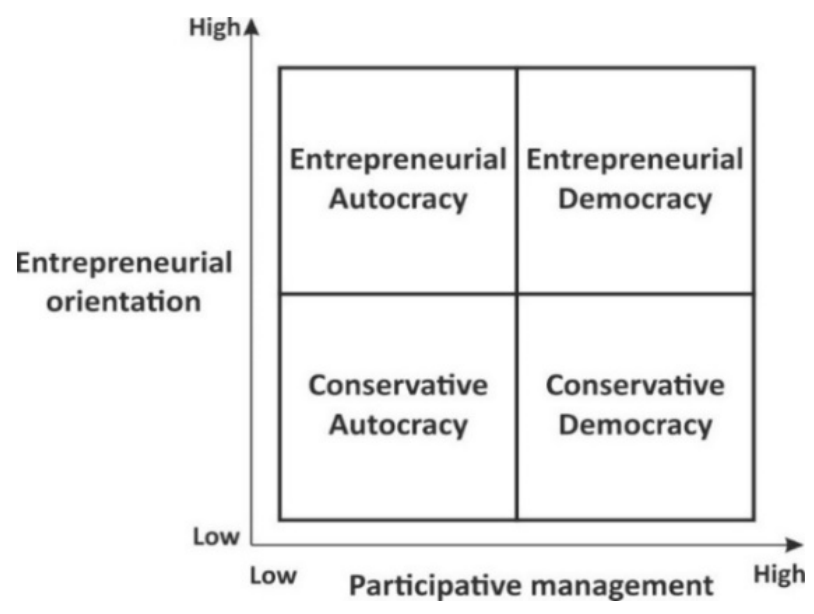

Figure 1. Graph Culture Types related to Dimensions

\subsection{Vox Research - Patent}

All of the above mentioned has been registered as a patent through our agent "Berin" with the Macedonian intellectual property right institute under number 908532. 
Patent protection was issued as of 19/09/2018.

\section{Proposal for Modification of the Instrument for Measuring of the Organizational Culture, Leader's Values and the Formal Part of the Organization "Vox 2.0."}

Why revision? First of all we have conducted a factor analysis at the University of Belgrade, Technical Faculty Bor. Our colleague prof. Ivan Mihjalovic suggested that we should shorten the four dimensions into three, based on the quantitative analysis. There were other issues troubling the Vox model 2011-2017. (Let us call this model Vox 1.0.) The first issue was the longevity of the questionnaire, ${ }^{1}$ which was considered to be complicated and less acceptable for the audiences. The second issue was the big number of combinations for culture and leadership types. Vox 1.0 model was based on sixteen possible outcomes for culture, leadership and the formal part, thus making it too complex, especially for presentation of the results. They were complex to be explained, even too complex to be graphically presented: (see appendix 1). This is why we propose a modification of the program. Main modifications are in two directions. The first and the most important is the shortening of the model from four to two dimensions. The second is the shortening of the questionnaire. Let us explain these alterations:

\subsection{New, Shorter Questionnaire}

The questionnaire was recomposed. There were many complaints about its longevity and the time needed to fulfill it. Now it contains only 21 questions for organizational culture and leadership style and 15 questions for the formal part. In Vox 2.0 we are implementing five point Likert scale instead of four points, with "neutral" as an option.

In terms of measuring culture and leader's values, the same approach as in the Vox 1.0 is employed. The questionnaire is the same for the "Members" and "Leader". The difference is that "Members" reply the "things as they are" and leader replies "things as they should be". "In cases where the analysis extends on finding similarities/differences in the different dimensions of organizational culture between different sectors in the organization, different approach will be instituted.,iii

The formal part of the organization can be evaluated via questionnaire composed of 15 questions, or structured interview with the leader. The interview is and should be structured around the same questions that are mentioned in the questionnaire. In the case of geographical distance,

1 Please refer to Apendix 3 video-conference can be applied. If regional teams are evaluated - regional team leader should be interviewed.

Another modification in the questionnaire is that we propose a five point Likert scale. Why? We propose this option to introduce a "neutral" option, because the review of Vox 1.0. model indicated forced "cut offs". There is a debate in the research community on this matter. ${ }^{23}$ Hereinafter, we shall focus on the suggestions for the modification of the model. We are discussing the three pillars: culture, leadership and the formal part of the organization.

\subsection{Vox 2.0 Culture Types (C4T)}

The term "culture" is one of the most ambiguous and variously defined concepts of what can be found in the literature. It is difficult to cite a single, common and recognized definition of organizational culture." (Wyrvicka and Chauda, 2019). Seminal work of Schein "talks about "culture" as: a pattern of basic assumptions-invented, discovered, or developed by a given group as it learns to cope with its problems of external adaptation and internal integration--that has worked well enough to be considered valid and, therefore, to be taught to new members as the correct way to perceive, think, and feel in relation to those problems" (Schein, 1992).

It is important to note that for reason of practicality we understand "organizational culture" and "values of the organization's members" as synonymous. The same approach is used by other authors, for instance Henri (Henri, 2006), who states that "organizational culture is defined as a set of dominant values, beliefs, and assumptions that govern how people behave in organizations."

The definition of the author is the following: "Organizational culture is an unwritten system of values and norms that determines interactions, behaviors, decision making and processes within the organizations."

As we have already mentioned, the original Vox instrument was based on four dimensions measured on two poles, thus enabling sixteen possible variations and sixteen culture types. We felt the need to shrink the number of variations of organizational culture from sixteen to four. There are many models in the management theory built on the two axis (two dimensions) and they all present results with four possible variations. We shall mention just some of them, like: Handy's classification of culture (Janicevic et al., 2018) and Gofee and Jones's typology of culture

2 For instance Ruth Maria Tappin from Capella University suggests the following: "The literature is not definitively clear about the use of mid-point categories on self-report Likert scales. For example, some sav that mid-point choices increase scale reliability (Courtenav \& Weidemann, 1985; Madden \& Klopfer, 1978), while detractors claim that mid-pointing could result in satisficing, (Krosnick, Narayan, \& Smith. 1996), which could cluster responses at the mid-point.

3 See Appendix 1 Comparative analysis of Questionnaire Vox 1.0 and Vox 2.0. 
(Malagaz et al., 2017)

Besides the new definition of organizational culture, our contribution to the management theory and practice is the typology of " 4 Culture Types" or as we'd like to call it, the "4CT". Those are: Entrepreneurial Autocracy; Entrepreneurial Democracy; Conservative or Managerial Autocracy and Conservative or Managerial Democracy, and they are based on two dimensions. Figure 1 Graphical presentation of the 4CT: Entrepreneurial Autocracy; Entrepreneurial Democracy; Conservative or Managerial Autocracy and Conservative or Managerial Democracy.

\subsection{Vox Leadership Types (L4T)}

We use the term leader's values and leadership styles interchangeably. This is due to our belief that values are the main determinants of the behaviors (Cohen, 2017). Concerning the link between culture and leadership, Schein (1989) suggests that "culture and leadership, when one examines them closely, are two sides of the same coin, and neither can really be understood on its own.” Further, he continues "the only thing of real importance that leaders do is create and manage culture and the unique talent of leaders is their ability to work with culture."

The author also believes that culture is linked with the leadership. This is why the author defines leadership as a process of leader's influence on followers in which the latter voluntarily accept stimulus from their former. So, the key elements of leadership are: 1) the process, 2) the stimulus from the leaders and the 3) voluntarily acceptance of those stimuli by the followers.

In Section 4.1 we discuss the two dimensional models of organizational culture. The same approach can be found with the leadership typologies. For instance Michigan studies; Ohio state; Situational leadership; Path goal; Spirituality and Integrity (Spiritual leadership (Yang, 2019) are based on two dimensions measured on two poles. Thus, it is methodologically justifiable to use a leadership styles typology model based on two dimensions:

- Decision Making styles (Democratic and Autocratic), and

- Entrepreneurship an Innovativeness ( Entrepreneurial or Risk Averse) style

For the purposes of a wider acceptance of our theory, we are linking our leadership styles with famous individuals, positions or types of businesses.

Thus, we define Entrepreneurial autocracy as being "Steve Jobs like Leadership style" (Agrawal, 2016) and Entrepreneurial Democracy as being "Jack Welch Like" leadership style (Chris, 2015). Steve Jobs was definitely one of the entrepreneurs and business leaders that have put a "dent on the universe" (Isaacson, 2012). But he was also considered a cold hearted and assertive type of leader. Some authors consider himself to have been "abrasive in nature" and "narcissist" (Rauch and Frese, 2007). Jack
Welch, on the other hand, being one of the "rock stars" in the business, is known for his participatory management style (Bartlett and Wozny, 1999).

Figure 2. Types of Leadership, with Four Main Leader's Types: "Steve Jobs" leader type; “Jack Welch" leader type, "Army officer" and "The Banker"

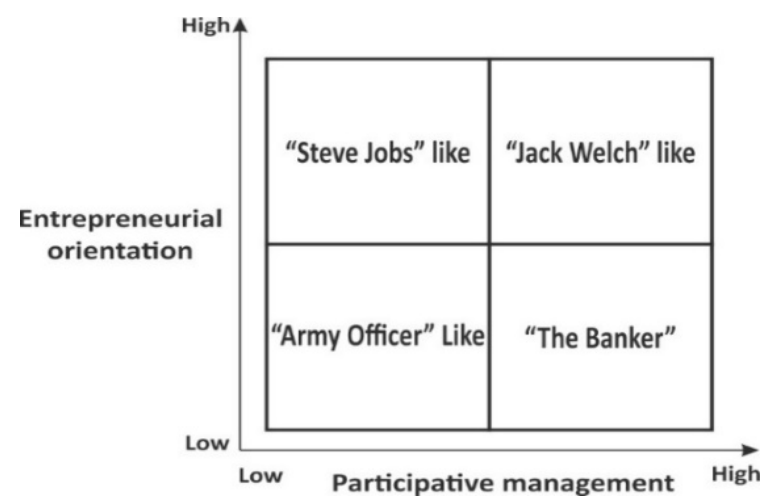

Figure 2. Graph Leader's Types related to Dimensions

\subsection{Formal Part of the Organization}

The formal part of the organization is any formal document, including but not limited to policies, procedures, strategic plans and the like that might influence the behavior. It might include documents like: remuneration policy, office hours, decision making process and any other policies and procedures that might be deemed relevant for the evaluation of organization's character.

\section{Organizational Alignment: Two Types}

Additionally, all aspects should be well aligned. Organizational alignment is the congruence between the values of organizational members and the values of the leader, and embedment of the same values in the formal part of the organization."

We propose a new Vox 2.0 instrument. The revision was conducted in the direction of two forms of Vox Alignment: Vox Standard, which measures the alignment between organizational culture and leader's values and Vox Standard Plus which measures the alignment between organizational culture leader's values and the formal part of the organization

\section{1. "Vox 2.0 Standard" Process Flow: Alignment between Organizational Culture and Leader's Values}

The following Chart No.1 illustrates the process of conducting the "Vox" Instruments. It starts with surveys values of the members and of the leader, resulting with assessment of culture. This "Step 1" results with: a) Evaluation of the dominant culture type and b) Evaluation of the dominant leadership type. 


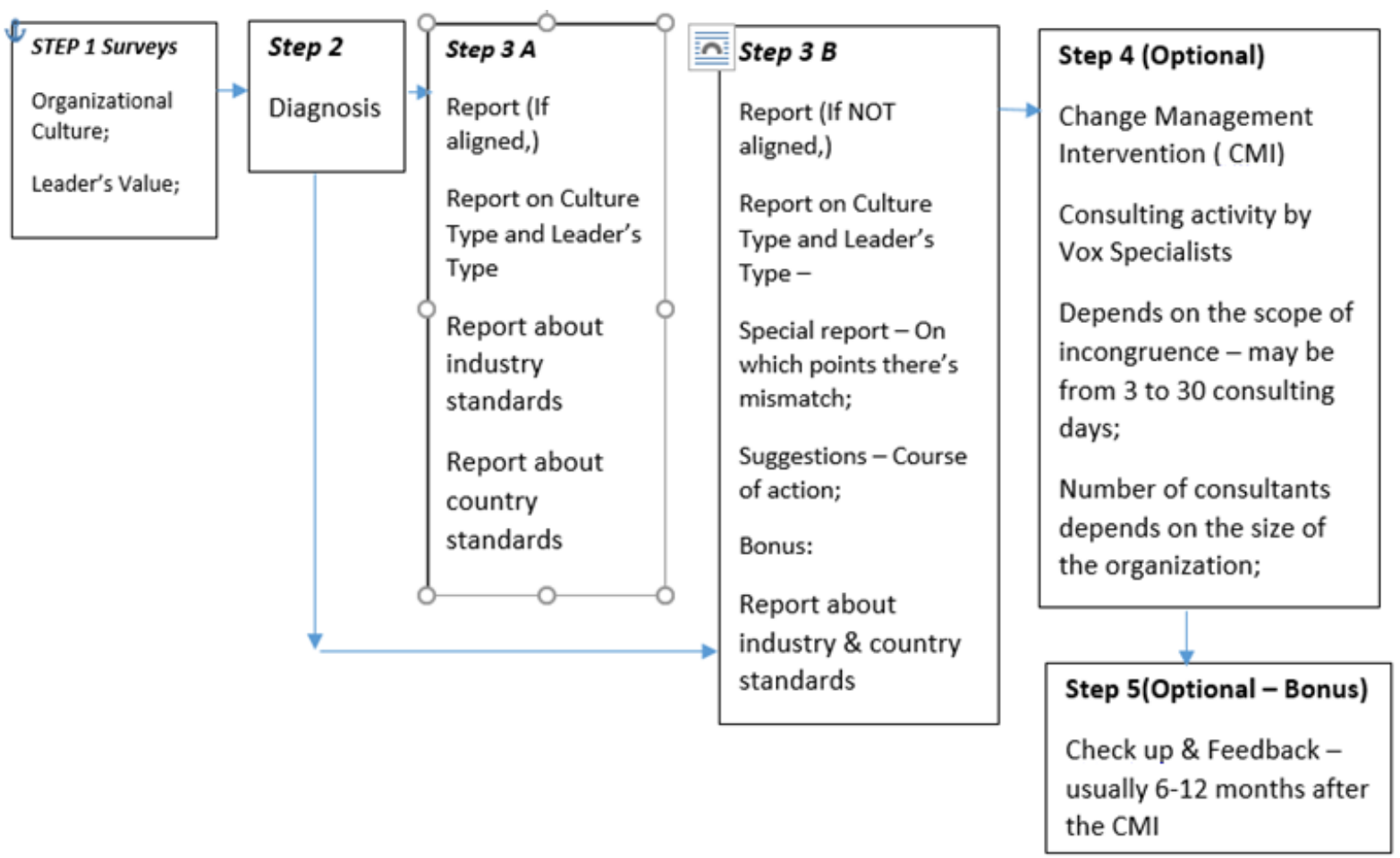

Figure 3. Vox Standard: Culture and Leader's Type Alignment

\section{2. "Vox 2.0 Standard Plus" Process Flow: or "The Importance of the Full Alignment"}

Furthermore, we have moved this analysis one step forward: How does the "formal part "of the organization align with the values of the leader and organizational culture? Here is one analysis based on our model (Andrade et al., 2017) and there were others in the business sector (Bojadjiev et al., 2016). This is based on the parable, spoken of so often by Marjan I. Bojadjiev (Bojadziev et al., 2011).

"The concept of alignment in any organization is very similar to a symphonic orchestra. The orchestra has many different instruments, some are very important for the concerto or for a particular part of the concerto, other perhaps wait for a long time in order to play their part. But, it is very important that they are all attuned and follow the master and their fellow musicians and they all play their part as perfectly as they possibly can. These similarities are also very important for a company or an organization. The company must align its players and instruments in order to enjoy the fine melody it produces" (Bojadziev et al., 2011). 
Major: Culture \& Leader's \& Formal Organization Alignment

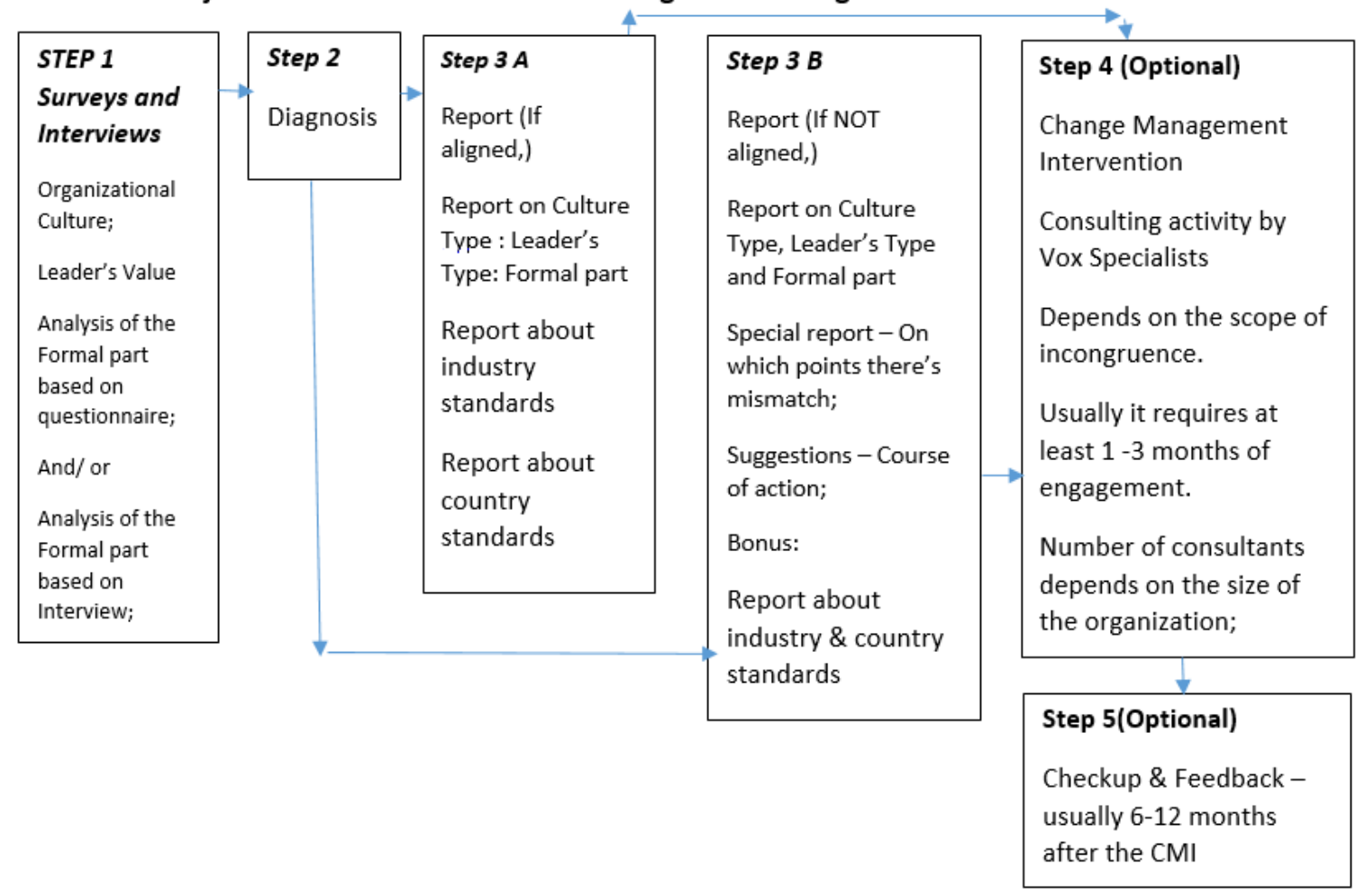

Figure 4. Vox Standard Plus: Culture, Leader's Values and Formal part Alignment

\section{3. "Vox Extended"}

There are three outcomes of Vox organizations: Vox Standard, which reports organizational culture type, leader's values and level of alignment between them; Vox Standard Plus, which reports the formal part of the organization and level of alignment between the former and the latter; and Vox Extended, which is tailor made consultancy project focused on change management intervention.

It is very important for any organization to be able to identify the needs in the future, and how to manage the changes required to get there. Vox Extended outcomes are consulting activities and change management intervention if needed. Change management is the "the process of continually renewing an organization's direction, structure, and capabilities to serve the ever-changing needs of external and internal customers” (Moran and Brightman, 2001).

\section{Conclusions and Further Research}

Finally, what is the purpose of having aligned organization if it is not more successful? If management is about the attainment of organizational goals more effectively, it is our job as management thinkers to assist the organizations in that endeavor. From here, we are raising the hypothesis that aligned companies are more efficient and effective. Another hypothesis arisen is that the efficiency is measured through three financial indicators: profitability; ROE and ROA and that efficiency for the non-profit organizations and institutions should be measured as the level of meeting the previously set key performance indicators (KPI-s) and/or level of satisfaction of the stakeholders. However, this is the challenge for our next research project.

Table 2. Four culture types and four leadership types

\begin{tabular}{|c|c|}
\hline Culture Types & Leader's Type \\
\hline Entrepreneurial Autocracy & $\begin{array}{c}\text { "Steve Jobs like” Leader } \\
\text { type }^{\text {iv }}\end{array}$ \\
\hline Entrepreneurial Democracy & $\begin{array}{c}\text { "Jack welch like” Leader } \\
\text { type }\end{array}$ \\
\hline $\begin{array}{c}\text { Conservative or Managerial } \\
\text { Autocracy }\end{array}$ & $\begin{array}{c}\text { "Army officer like” Leader } \\
\text { Type }\end{array}$ \\
\hline $\begin{array}{c}\text { Conservative or Managerial } \\
\text { Democracy }\end{array}$ & "Banker like” Leader type \\
\hline
\end{tabular}




\section{Appendix 1}

\section{Graphic Presentation of the Two Examples, out of Sixteen Possible Combinations}

\begin{tabular}{|l|l|}
\hline $\begin{array}{l}\text { F1- Positive on Participative Managerial Style, } \\
\text { F2 - Warm Work Environment, }\end{array}$ & $\begin{array}{l}\text { F1 - Positive on Participative Managerial Style, } \\
\text { F2 - Cold Work Environment, } \\
\text { F3 - Open System, and } \\
\text { F4 - Entrepreneurial Organization }\end{array}$ \\
\hline F4 - Risk-Averse Organization; &
\end{tabular}

\section{Appendix 2}

\section{Questionnaire for Employees and Leaders - Measurement of Organizational Culture and Leadership Style ${ }^{4}$}

\begin{tabular}{|c|c|c|c|c|c|}
\hline & 1- Strongly disagree & 2-I disagree & 3- Neither Agree Nor Disagree & 4-I agree & 5-I strongly agree \\
\hline \multicolumn{6}{|c|}{ PART I. DEMOCRATIC VERSUS AUTOCRATIC ORGANIZATION } \\
\hline \multicolumn{6}{|c|}{ Decision-Making and Behavior } \\
\hline 1. & \multicolumn{5}{|c|}{ The organization has "clear rules of the game" } \\
\hline 2. & \multicolumn{5}{|c|}{ There is an atmosphere of trust in the organization } \\
\hline 3. & \multicolumn{5}{|c|}{ When changes are made, decisions are made publicly and timely to the respective parties } \\
\hline 4. & \multicolumn{5}{|c|}{ Managers consult with subordinates in the decision-making process } \\
\hline 5. & \multicolumn{5}{|c|}{ Strategic decision-making process takes place in accordance with written rules and procedures } \\
\hline 6. & \multicolumn{5}{|c|}{$\begin{array}{l}\text { The organization is confident that employees will work according to accepted organizational norms and standards in cases where } \\
\text { there are no written ones }\end{array}$} \\
\hline 7. & \multicolumn{5}{|c|}{ There is a shared understanding of the appropriate behavior in the organization } \\
\hline \multicolumn{6}{|c|}{$\begin{aligned} & \text { People vs Task Oriented } \\
&\end{aligned}$} \\
\hline 8. & \multicolumn{5}{|c|}{ The organization provides opportunities for professional development and growth to the employees } \\
\hline 9. & \multicolumn{5}{|c|}{ The organization respects its employees and treats them consistently and fairly } \\
\hline 10. & \multicolumn{5}{|c|}{ The organization takes care of work-life balance } \\
\hline 11. & \multicolumn{5}{|c|}{ The organization pays little attention to the conditions of the workplace and working conditions } \\
\hline 12 & \multicolumn{5}{|c|}{ Employees receive timely feedback (formal or informal) about their work } \\
\hline \multicolumn{6}{|c|}{ Open vs. Closed System } \\
\hline 13. & \multicolumn{5}{|c|}{ The organization fosters collaboration among employees in the same sector } \\
\hline 14. & \multicolumn{5}{|c|}{ The organization encourages cooperation between different sectors } \\
\hline \multirow[t]{3}{*}{15.} & \multicolumn{5}{|c|}{ The organization develops community relations (municipality, chambers and thus like) } \\
\hline & \multicolumn{5}{|c|}{ PART II. ENTREPRENEURIAL ORIENTATION } \\
\hline & \multicolumn{5}{|c|}{ Innovative vs. Risk Taking } \\
\hline 16. & \multicolumn{5}{|c|}{ The organization encourages experimenting and trying out new activities and approaches } \\
\hline 17. & \multicolumn{5}{|c|}{ Employees are encouraged to develop new and original ideas and/or products } \\
\hline 18. & \multicolumn{5}{|c|}{ The organization supports stability as a prerequisite for long-term sustainability } \\
\hline 19. & \multicolumn{5}{|c|}{ The organization does not take risks, uses a tried and tested approach } \\
\hline 20. & \multicolumn{5}{|c|}{ The organization invests in learning new things } \\
\hline 21. & \multicolumn{5}{|c|}{ The organization creates an atmosphere of trust that failure in new projects will not be deemed inappropriate; } \\
\hline \multicolumn{6}{|c|}{$\begin{array}{l}\text { NOTE: In Part I there are three subgroups: Decision making and behavior, People versus Task Oriented and Open and Closed system. All } \\
\text { three are part of the "Democratic versus Autocratic" dimension/ The subgroups can be used for deeper analytics. }\end{array}$} \\
\hline
\end{tabular}


Questionnaire for Employees and Leaders - Measurement of the Formal Part of the organization ${ }^{5}$

\begin{tabular}{|c|c|c|c|c|c|}
\hline & 1- Strongly disagree & 2-I disagree & 3- Neither Agree Nor Disagree & 4-I agree & 5-I strongly agree \\
\hline \multicolumn{6}{|c|}{ PART I. DEMOCRATIC VERSUS AUTOCRATIC ORGANIZATION } \\
\hline \multicolumn{6}{|c|}{ Decision-Making and Behavior } \\
\hline 1. & \multicolumn{5}{|c|}{ Does the organization have written policies and procedures (relevant for questions 1,5 )? } \\
\hline 2. & \multicolumn{5}{|c|}{ Does the organization have a formal organizational structure? } \\
\hline 3. & \multicolumn{5}{|c|}{ Does the organization have clearly defined duties and responsibilities for each employee? } \\
\hline 4. & \multicolumn{5}{|c|}{ Is there a written procedure according to which employees can express their opinion to the management? } \\
\hline 5. & \multicolumn{5}{|c|}{ Does the organization have a strategic plan? } \\
\hline 6. & \multicolumn{5}{|c|}{$\begin{array}{l}\text { Are the managers at the lower level and the employees that are relevant to the process consulted in the process of developing the } \\
\text { strategic plan? }\end{array}$} \\
\hline \multicolumn{6}{|c|}{ People vs. Task Oriented } \\
\hline 7. & \multicolumn{5}{|c|}{ Does the organization have a formal document addressing work life balance (flexible work hours, absences, vacations)? } \\
\hline 8. & \multicolumn{5}{|c|}{ Does the organization have a formal documents and bylaws addressing professional envelopment of the employees? } \\
\hline \multicolumn{6}{|c|}{ Open vs. Closed System } \\
\hline 9. & \multicolumn{5}{|c|}{ Is there a formal policy, or bylaw that stimulates internal communication (cross functional teams, sharing of ideas,)? } \\
\hline 10. & \multicolumn{5}{|c|}{ Is there a formal policy for encouraging team work and intradepartmental, or interdepartmental collaboration? } \\
\hline & \multicolumn{5}{|c|}{ PART II. ENTREPRENEURIAL ORIENTATION } \\
\hline \multicolumn{6}{|c|}{ Innovative vs. Risk Taking } \\
\hline 11. & \multicolumn{5}{|c|}{ Does a company have a system to reward (encourage) innovativeness of its employees? } \\
\hline 12. & \multicolumn{5}{|c|}{$\begin{array}{l}\text { Does the organization have a system/bylaws/procedure according to which employees are free to experiment with new products and } \\
\text { services, and eventual costs are covered by the organization itself? }\end{array}$} \\
\hline 13. & \multicolumn{5}{|c|}{$\begin{array}{l}\text { Does a company have a system/bylaws/procedure according to which employees can express their idea for new products and } \\
\text { services, or improvement of the existing ones etc.? }\end{array}$} \\
\hline 14. & \multicolumn{5}{|c|}{ Does the strategic plan includes some type of innovativeness (launching new products or services, targeting new markets or clients? } \\
\hline 15. & \multicolumn{5}{|c|}{ Does the organization have an organizational unit with main goal innovation? } \\
\hline
\end{tabular}




\section{Appendix 3. The Vox Questionnaire- First Version before Being Revised}

\begin{tabular}{|c|c|c|c|}
\hline $\begin{array}{l}\text { 1- Strongly } \\
\text { disagree }\end{array}$ & 2-I disagree & 3-I agree & 4-I strongly agree \\
\hline \multicolumn{4}{|c|}{ PART I. DEMOCRATIC VERSUS AUTOCRATIC ORGANIZATION } \\
\hline \multicolumn{4}{|c|}{ Decision-Making and Behavior } \\
\hline 1. & The organization has "cl & & \\
\hline 2. & There is an atmosphere $c$ & ation & \\
\hline 3. & When changes are made, & publicly and & parties \\
\hline 4. & Leaders and managers cc & tes in the de & \\
\hline 5. & The organization has wri & cedures & \\
\hline 6. & Achieving the results is $\mathrm{r}$ & following th & \\
\hline 7. & The decisions are central & & \\
\hline 8. & $\begin{array}{l}\text { The employees are trus } \\
\text { governed by organizatiol }\end{array}$ & $\begin{array}{l}\text { to organiz } \\
\text { ires }\end{array}$ & is and standards in situations not \\
\hline 9. & There is a shared underst & riate behavi & \\
\hline 10. & The organization provide & portunities $\mathrm{f}$ & ment and growth \\
\hline 11. & The organization takes c & sphere and & \\
\hline 12. & The organization respect & treats them & lanner \\
\hline 13. & The organization is only & eople do & \\
\hline 14. & The organization conside & e lives as th & \\
\hline 15. & The organization pays lit & cal work en & \\
\hline 16. & The management is sting & & \\
\hline 17. & Employees receive timel & r informal) & \\
\hline 18. & The organization encour & and trying ou & \\
\hline 19. & Employees are encourag & ad original ic & \\
\hline 20. & Employees are encourag & oat” & \\
\hline 21. & The organization conside & propriate le & y to build long term sustainability \\
\hline 22. & The organization cherish & equisite for $t$ & \\
\hline 23. & The organization does nc & tried and te & \\
\hline 24. & Employees and the orgar & neers & \\
\hline 25. & The organization encour & tal collabor & \\
\hline 26. & The organization encour & th collaborati & \\
\hline 27. & The organization encour & ith customer & \\
\hline 28. & The performance manag & ts group wo & \\
\hline 29. & The organization strives & & \\
\hline 30. & The organization invests & & \\
\hline 31. & The organization does nc & ith local con & \\
\hline 32. & The organization and pec & ecretive & \\
\hline 33. & In this organizations new & re than a ye & \\
\hline 34. & The organization puts en & ustomer nee & \\
\hline 35. & The organization nurture & ion with oth & ey are competitors \\
\hline
\end{tabular}




\section{List of Acronyms}

\begin{tabular}{|c|c|}
\hline Acronyms & Words \\
\hline 4CT & Four Culture Types \\
\hline 4LT & Four Leadership Types \\
\hline OCAI & Organizational Culture Assessment Instrument \\
\hline UACS & University American College Skopje \\
\hline OCP & Organizational Culture Profile \\
\hline
\end{tabular}

\section{REFERENCES}

[1] Agrawal.A. (2016). Jobs or Gates: Differences in Leadership. Online at:https://www.inc.com/aj-agrawal/jobs-or-gates-di fferences-in-leadership.html.Last accessed: October 7,2019

[2] Aktas., E., Cicek, I., Kiyak. M. (2011). The Effect of Organizational Culture On Organizational Efficiency: The Moderating Role Of Organizational Environment and CEO Values, Vol.24, p.1560-1573

[3] Andrade, M.S.O., Goksel.A. (2017). “Organizational Alignment Case Study of Ministry of Justice of Cape Verde” International Journal of Business and Management Invention, 6(4), p.25-35

[4] Bartlett, Christopher A., and Meg Wozny. (1999)."GE's Two-Decade Transformation: Jack Welch's Leadership." Harvard Business School Case 399-150.

[5] Bass,B,M., Avolio,B.J. (1993). Transformational Leadership and Organizational Culture, Public Administration Quarterly, 17(1), p.112-121

[6] Bojadziev, M., Tomovska Misoska, A., Stefanovska, M., \& Nikolovska, Z. (2011). Vox organizationis - theoretical basis and methodological considerations in the development of an instrument for organizational culture, Munich Personal RePec Archive Working Paper, Retrieved from: http://mpra.ub.uni-muenchen.de/42571/.

[7] Bojadjiev.M., Tomovska Misoska. A., Pesev. A., Stefanovska-Petkovska. M.(2016). "Organizational Alignment in ICT Company in the Republic of Macedonia” Business and Economic Research, 6 (2), p.424-439

[8] Bojadziev, M., Naumovski S., Tomovska Misoska, A. and Stefanovska Petkovska, M. (2016). Organizational alignment in the food industry: Case study of a company in the Republic of Macedonia, Journal of the Institute of Economics-Skopje.

[9] Bojadjiev, M., Kostovski, N., Krliu-Handjiski, V. \& Shindilovski, D. (2017). Organizational Culture and Strategic Alignment in fast Moving Consumer Goods Company”, Annual of ISPJR, 41 (1), p.45-56

[10] Bojadjiev, M., Tomovska Misoska, A., Mirocevic, B. and Stefanovska-Petkovska, M. (2018). Organizational Culture and the "Voice" of Small Enterprises in the Electrical Engineering Service Sector in the Republic of Macedonia, Universal Journal of Management (6)8: 263-272.

[11] Cameron, K. and R. E. Quinn. (2006). Diagnosing and
Changing Organizational Culture: Based on the Competing Values Framework. 3th ed, San Francisco, CA, Jossey Bass

[12] Chris.J. (2015).11 Jack Welch Leadership Style Axioms. Online at: http://www.josephchris.com/11-jack-welch-lead ership-style-axioms. Last accessed: October 7, 2019

[13] Cohen.H. (2017). Values and Beliefs Determinants of Behavior. Online at:https://www.herbcohenonline.com/val ues.htm. Last accessed: October 7,2019

[14] Cooke, R.A. and Szumal, J.L. (2000). Using the Organizational Culture Inventory ${ }^{\circledR}$ to Understand the Operating Cultures of Organizations. In Ashkanasy, N.M

[15] Deen,L .(2011). Intel Advances into new realms-Sets a new standard by focusing on the most important asset they have: people, USBE\&IT, 35(3), p.21-22

[16] Denison,D. (2018).Organizational Culutre Survey Overall, Retreived from: https://www.denisonconsulting.com/, Last accessed: January 9,2018

[17] Denison,D., \& Mishra,A,K,. (1989). Organziational culture and effectiveness: A Theory and some preliminary empirical evidence, Academy of Management Annual Meeting Proceedings, Vol.1, p.168-172

[18] Dickson, M.W., Aditya, R.N. \& Chhokar, J.S (2000) Definition and interpretation in crosscultural organizational culture research. In N.M. Ashkanasy, C.P.M. Wilderom and M.F. Peterson (Eds.) Handbook of organizational culture and climate, p.447-464, Thousand Oaks: Sage.

[19] Fiaz, M,.Ikram.A.,Su.Q.,Saqib.A.(2017). Leadership styles and employees motivation: Perspective from an emerging economy, The Journal of Developing Areas, 51(4), p.143-156

[20] Fiedler, F.E. (1996) 'Research on Leadership Selection and Training: One View of the Future', Administrative Science Quarterly, 41: 241-50.

[21] Freifeld, L. (2013). Emerging Training Leaders. Training, 50(3), 20-31

[22] Henri, J.-F. (2006). Organizational culture and performance measurement systems. Accounting, Organizations and Society, 31(1), 77-103.

[23] Hinshaw.K. (2015). “Organizational Alignment Is The Key To Managing Change” Retrieved from: https://leadchange group.com/organizational-alignment-is-the-key-to-managi ng-change/, Last accessed: January 9,2018

[24] Hofstede, G. (1998). Attitudes, values and organizational culture: Disentangling the concepts. Organization Studies, Vol. 19(3), p. 477-492.

[25] Hofstede, G., Neuijen, B., Ohayv, D.D. \& Sanders, G. (1990). Measuring organizational cultures: A qualitative and quantitative study across twenty cases, Administrative Science Quarterly, Vol. 35, p. 286-318.

[26] Husain M., hasan J., : “The leadership styles dilemma in the business world” International Journal of Organizational Leadership 5(2016) 411-425

[27] Isaacson.W. (2012). The Real Leadership of Steve Jobs. Online at: https://hbr.org/2012/04/the-real-leadership-lesso ns-of-steve-jobs. Last accessed: October 7, 2019 
[28] Jaivisarn, V. (2010). How organizational culture of Japanese multinationals in Thailand influences Japanese-speaking Thai employees' organizational commitment, Journal of International Business and Economics, 10 (1), p. 106-120

[29] Janićijević .N., Nikčević.G., Vasić Vladimir. (2018). The influence of organizational culture on job satisfaction. Economic Annals 2018 Volume 63, Issue 219, Pages: 83-114

[30] Krleska A.(2015)"'Organizational Alignment in Higher Education - A Case Study of Macedonian Higher Education Institution”, Mater Thesis, University American College Skopje,Macedonia

[31] Limani,A.,Tomovska-Misoska,A., and Bojadjiev,M. (2015). Organizational alignment as a model for sustainable development in the public sector in the Republic of Macedonia. Journal of Sustainable Development, Vol.5 (2).p.51-68. Integrated Business Faculty, Skopje, Macedonia

[32] Malagas.K., Gritazalis.S., Nikitakos.N., Fragoudaki.A. (2017). The implementation of Goffee and Jones's types of organizational culture ina greek state-owned organzaition that introduced new technologies. Foundations of Management, Vol. 9 , ISSN 2080-7279

[33] Merron, K, A, (1994). Creating TQM organizations. Qualify Progress, Vol. 27 (1), p. 51-54.

[34] Mihai.S.L.(2015). The particularities of Leadership Styles among Dutch Small and Medium Business Owners, Annals of the „Constantin Brâncuşi” University of Târgu Jiu, Economy Series, Vol.6, p.240-248

[35] Mistry, P. (2017). Richard Branson: "Clients do not come first. Employees come first.” Available at: Richard Branson: "Clients do not come first. Employees come first." Last accessed January 9, 2018

[36] Moran, J. W. and Brightman, B. K. (2001) 'Leading organizational change’, Career Development International, 6(2), pp. $111-118$

[37] Nazir, A.N. (2005). Person-culture fit and employee commitment in banks. Journal for Decision Makers, 30 (3), p. 39-51.

[38] Nadler, D, A, Tushman, M, L, (1989). A model for diagnosing organizational behavior: Applying a congruence perspective. In D. A. Nadler, M. L. Tushman, C. O'Reilly (Eds,), The management of organizations: Strategies, tactics, analyses, p, 91-106, New York: Harper \& Row.

[39] Naumovski S, Bojadjiev M, Misoska A., Stefanovska M: Al "Organizational Alignment in the food industry: Case Study of a company in the republic of Macedonia" Journal of the Institute of Economics Skopje, I-2016

[40] Odiakaose,H. (2018). Organizational culture and dynamics. International Journal of Scientific Research and Management, Vol 6 (1), p.31-39

[41] O'Reilly.C.A, Chatman,J., CaldwellD.F., (1991). People and organizational culture: A profile comparison approach to assessing person-organization fit, Academy of Management Journal 34(3), p. 487-516

[42] Ogbonna.E.,Harris ～L.C. (2000).Leadership style, organizational culture and performance: empirical evidence from UK companies, The International Journal of Human Resource Management,11(4) ,p.766-788

[43] Pesev A., Bojadziev M., Tomovska A., Stefanovska M: "Organizational alignment in the ICT Company" Business and Economic Research, 2016, Vol. 6, No. 2

[44] Quiros.S.I. (2009).Organizational alignment: A model to explain the relationships between organizational relevant variables. International Journal of Organziational Analysis, Vol.17(4), p.285-305

[45] Rauch, A., \& Frese, M. (2007). Born to Be an Entrepreneur? Revisiting the Personality Approach to Entrepreneurship. In J. R. Baum, M. Frese, \& R. A. Baron (Eds.), The organizational frontiers. The psychology of entrepreneurship (pp. 41-65). Mahwah, NJ, US: Lawrence Erlbaum Associates Publishers.

[46] Schneider, R. R., J. B. Stelfox, S. Boutin, \& S. Wasel. (2003). Managing the cumulative impacts of land uses in the Western Canadian Sedimentary Basin: a modeling approach. Conservation Ecology 7(1):8. [online] URL: http://www.consecol.org/vol7/iss1/art8/

[47] Semler, S. W. (1997) Systematic Agreement: A Theory of Organizational Alignment, Human Resource Development Quarterly, 8(1), p.23-40, EBSCOhost, [Accessed date 18/09/2017]

[48] Schein, E.H. (1990). Organizational culture. American Psychologist, 45(2), p. 109-119.

[49] Schein, E.H. (1992) Organizational Culture and Leadership, 2nd edn. San Francisco: JosseyBass.

[50] Schriesheim.A.C, Bird.B.J (1979). Contributions of the Ohio State Studies to the Field of Leadership, Journal of Management, 5(2), p. 135-145.

[51] Singh, K. (2007). Predicting organizational commitment through organization culture: A study of automobile industry in India, Journal of Business Economics and Management, Vol. 8 (1), p. 29-37

[52] Tosti, D. (2007). Aligning the culture and strategy for success, Performance and Improvement, 46(1), p.21-25

[53] Weiser, J. 2000. Organizational Alignment: Are We Heading In The Same Direction. The Kansas Banker, 90, 11-15.

[54] Wyrwicka.K.M., Chuda. A. (2019). "The diagnosis of organizational culture as a change factor in the context application of design thonking”, Logforum 15 (2), 9. DOI: 10.17270/J.LOG.2019.319

[55] Yang.F., Liu.J., Wang.Z., Zhang.Y. (2019).Feeling Energized: A Multilevel Model of Spiritual Leadership, Leader Integrity, Relational Energy, and Job Performance. Journal of Business Ethics, Springer, vol. 158(4), pages 983-997

i See more at http://bojadjiev.info/home/publications/ (accessed 01/23/2019)

ii Both charts are from Master Thesis of Mr. Antoni Pesev (pages 79, 80) iii "In cases where the analysis extends on finding similarities/differences in the different dimensions of organizational culture between different 
sectors in the organization a t-test will be used to test whether there are statistically significant differences between the sectors (Smith and Albaum, 2013). This test can also be used or testing differences connected to leader's values in situation where there is a need for having opinions from managers of different levels. Such example would be an organization with a head office and a number of regional offices where we might have to take into consideration both the opinion of the upper level of management and the regional managers as well.” (Tomovska Misovska 2019)

iv Originally was proposed by Ana Krleska in different context though. 